\title{
Reflecting rehabilitation nursing care: Theory of Recognition crossed by the Principle of Hope
}

\author{
Refletindo o cuidado de enfermagem de reabilitação: Teoria do \\ Reconhecimento atravessada pelo Princípio da Esperança \\ Reflejando el cuidado de enfermería de rehabilitación: Teoría del \\ Reconocimiento atravesada por el Principio de la Esperanza
}

\author{
Milena Amorim Zuchetto \\ Soraia Dornelles Schoeller ${ }^{\mathrm{a}}$ \\ Caroline Porcelis Vargas ${ }^{\mathrm{a}}$ \\ Lucas Antunes ${ }^{a}$ \\ Mara Ambrosina de Oliveira Vargas ${ }^{\mathrm{a}}$
}

How to cite this article:

Zuchetto MA, Schoeller SD, Vargas CP,

Antunes L, Vargas MAO. Reflecting reha-

bilitation nursing care: Theory of Recognition crossed by the Principle of Hope. Rev Gaúcha Enferm. 2021:42:e20200093. doi: https://doi.org/10.1590/19831447.2021.20200093
Universidade Federal de Santa Catarina (UFSC) Centro de Ciências da Saúde, Departamento de Enfermagem. Florianópolis, Santa Catarina, Brasil.

\section{ABSTRACT}

Objective: The study seeks to reflect on rehabilitation nursing care, from the perspective of the Theory of Recognition and the Principle of Hope.

State of art: Reflection study, based on Axel Honneth's Theory of Recognition crossed by Ernst Bloch's Principle of Hope, aiming to elucidate the theoretical and methodological potential of these references for future research in health, nursing and rehabilitation nursing. Rehabilitation nursing care is permeated by theoretical and philosophical influences little described in the literature. The study proposes a way of thinking and exercising care with the perspective of building rehabilitation nursing care, in which the nurse excels in trust, respect and mutual esteem, playing the role of agent of hopeful and realistic expectations.

Conclusion: The study showed the main characteristics of each philosophical theoretical axis, permeating, separately, the relevant definitions to understand its implications in the concrete reality of living.

Keywords: Nursing care. Rehabilitation. Philosophy, nursing.

\section{RESUMO}

Objetivo: 0 estudo busca refletir sobre o cuidado de enfermagem de reabilitação, sob a ótica da Teoria do Reconhecimento e do Princípio da Esperança.

Estado da Arte: Estudo de reflexão, fundado na Teoria do Reconhecimento de Axel Honneth atravessada pelo Princípio da Esperança de Ernst Bloch, visando elucidar as potencialidades teórico-metodológicas desses referenciais para as futuras pesquisas em saúde, enfermagem e enfermagem de reabilitação. 0 cuidado de enfermagem de reabilitação é permeado por influências teórico-filosóficas pouco descritas na literatura. 0 estudo propoe uma forma de pensar e exercer 0 cuidado com a perpectiva de construir um cuidado de enfermagem de reabilitação, no qual o enfermeiro prima pela confiança, pelo respeito e estima mútua, exercendo o papel de agenciador de expectativas esperançosas e realísticas.

Conclusão: 0 estudo evidenciou as principais características de cada eixo teórico filosófico, permeando, separadamente, as definições relevantes para compreender suas implicações na realidade concreta do viver.

Palavras-chave: Cuidados de enfermagem. Reabilitação. Filosofia em enfermagem.

\section{RESUMEN}

Objetivo: El estudio busca reflexionar sobre la atención de enfermería en rehabilitación, desde la perspectiva de la Teoría del reconocimiento y el Principio de la esperanza.

Estado del arte: Estudio de reflexión, basado en la Teoría del reconocimiento de Axel Honneth, cruzado por el Principio de esperanza de Ernst Bloch, con el objetivo de dilucidar el potencial teórico y metodológico de estas referencias para futuras investigaciones en salud, enfermería y rehabilitación en enfermería. La atención de rehabilitación en enfermería está impregnada de influencias teóricas y filosóficas poco descritas en la literatura. El estudio propone una forma de pensar y ejercer la atención con la perspectiva de construir la atención de enfermería de rehabilitación, en la que la enfermera se destaca en la confianza, el respeto y la estima mutua, desempeñando el papel de agente de expectativas esperanzadoras y realistas.

Conclusión: El estudio mostró las principales características de cada eje teórico filosófico, que impregna, por separado, las definiciones relevantes para comprender sus implicaciones en la realidad concreta de la vida.

Palabras clave: Atención de enfermería. Rehabilitación. Filosofía en enfermería. 


\section{口INTRODUCTION}

This article of theoretical, philosophical and sociological reflection represents the continuity of an intellectual investment by the authors in understanding rehabilitation nursing care permeated with contradictions, aiming to deepen the nursing paradigms from the perspective of the Theory of Recognition by Axel Honneth ${ }^{(1)}$ and the Ernst Bloch's Principle of Hope ${ }^{(2)}$.

The articulation of the two theoretical perspectives consolidates the inseparable complexity contained in the nature of care, while its integrating personality presupposes a deep and singular knowledge of the other. In the caring attitude, the nurse act respecting the other in their personal and collective dimensions, in order to affirm their commitment to empowering the subject in their decision-making ${ }^{(3)}$.

Rehabilitation transcends human nature, through autonomy and expression of freedom as states of consciousness experienced personally and collectively. In this way, rehabilitative care encourages action and reflection about the reality of a singular life, critically revealing the valorization of the relationships between nurses and individuals. In other words, rehabilitation care has a constructive and procedural character, involving liberating autonomy in decision making. In the case of rehabilitation nursing, this occurs after a moment of life disruption, for example, the situation of disabling illness or disease, with emotional, social and financial commitment to individuals and families, founding care with a search for the reconquest and reconstruction of personality in an individualized way ${ }^{(4)}$. In this sense, this reflection invites students and nursing professionals to rethink and expand interpretive horizons.

This focus of rehabilitation nursing, in valuing the individual potential with its particularities, consists by the continuous "(re)construction" of the collective, critical and responsible identity ${ }^{(2)}$, representing a gap in the scientific literature, as well as a paradigm shift of care and, therefore, makes this process so special in nursing ${ }^{(5)}$. That said, the need for this research is justified by the paradigmatic breakdown of the concept of care "by"the other to care "with" the other, rebounding on a critical and decisive look for the development of full awareness, while it considers the intellectual investment directed to scientific and philosophical literature on rehabilitation nursing care. There is, in fact, a movement that questions the current conception of care, insisting on a counter-normative perspective of medical hegemony, inferring concepts of love, law, solidarity, autonomy, freedom and hope, aiming at enhancing the power of the will and the personal growth through experiences.

Thus, the guiding question of the study is how to reflect rehabilitation nursing care, considering the Theory of Recognition (1), as a sociological bias, and the Principle of Hope ${ }^{(2)}$ as a philosophical bias? Therefore, this article unfolds with the purpose of reflecting on the rehabilitation nursing care, based on these theoretical premises, bringing to light the theoretical and methodological potential of these references for scientific research in health and nursing, as well as the deep reflection of concreteness and the contradictions of this philosophical axis in rehabilitation nursing care.

\section{STATE-OF-THE-ART}

It is a reflection study, which was based on two theoretical bases, the sociological bias founded on the Axel Honneth's Theory of Recognition (1) and the philosophical bias based on Ernst Bloch's Principle of Hope ${ }^{(2)}$, in addition to the literary basis of current scientific bibliographies. To obtain these data, it was used state-of-the-art scientific literature in conjunction with the multiplicity ${ }^{(6)}$ of proposals, which generated a consistent panorama of complex concepts on health and rehabilitation nursing.

These studies are presented in the body of this manuscript as an instrument to support the contemporaneity of the studied thematic. In view of the findings and reflections inferred by the authors, the text was organized into three topics: (Re)knowing the Theory of Recognition by Axel Honneth Hoping and the Principle of Hope by Ernst Bloch; Theoretical possibilities of research in health, nursing and rehabilitation nursing. These topics were discussed about the dimensions of rehabilitation nursing care as a process of Recognition crossed by the Principle of Hope.

The aforementioned topics were elaborated based on the intersection of the Theory of Recognition, the Principle of Hope and rehabilitation nursing care, precipitating in considerations about clinical practice and possibilities of application in health and rehabilitation. Initially, the investigation tries to base the sociological and philosophical crossings to support the study proposal. Then, the encounters and mismatches of both theories are reflected on the foundation of their relations of dialectical reciprocities. Until the authors reach the propositional practices of theoretical reflection. 


\section{(RE)KNOWING AXEL HONNETH'S THEORY OF RECOGNITION}

Axel Honneth is a professor of philosophy at the University of Frankfurt, Germany, where he was born in 1949. His work focuses on social-political and moral philosophy, especially the relations of power, recognition, and respect. One of its main arguments is the priority of inter-subjective relations of recognition in the understanding of social relations. This includes non-recognition and misrecognition as the basis for social and interpersonal conflicts. His philosophical explanations are based on Hegel and psychosocial origin in Mead, aiming to fruit the understanding of recognition, while reflecting on the relationships between people ${ }^{(1)}$.

This Theorist seeks to explain the dynamics of social transformations and conflicts, based on conflicting injustice in concrete society. However, this struggle is counter-argued through three central axes: love, law, and solidarity. This eliminates the centrality of relationships in economic inequality, beginning to understand it as an experiential process of identity formation through intersubjective relationships ${ }^{(7)}$.

These forms of recognition constitute intersubjective protective devices, that ensure human freedom in an intimate, dignified, respectful and public manner for the formation of a personality with social esteem. The liberating action process depends on the spontaneous articulation of individual goals, based on the singular life story. This freedom as a result of recognition, is the real human self-realization, encompassing civil law and decision making in an equal way in society ${ }^{(7)}$.

That said, the subject only understands himself through the objective realization of his intersubjective pretensions, that is, the subject conceives himself as someone recognized, from the relationship with the other, pointing out his skills and qualities, generating the reconciliation and formation of a distinct and particular identity ${ }^{(4)}$.

The first axis of recognition, love, begins in intimate and trusting relationships, promoting the acceptance and participation of a member in his community, based on the reciprocal recognition of widespread self-understanding. It is from this primary relational process that mutual self-confidence arises, boosting liberation towards independence from oneself and the other ${ }^{(8)}$.

The second axis of recognition, the law, involves an understanding of equality, respect and dignity. This level of recognition assumes that the person has the ability to decide rationally on moral issues, legitimizing moral imputability and the rational legitimacy agreement between people on an equal situation. It is through this process of law, which allows the person to become aware of being able to respect himself, because he deserves the respect of others ${ }^{(7)}$.
The last axis of recognition, called solidarity, refers to the individually public capacities of esteem or socio-cultural status, which value the different private properties. Social appreciation occurs through cultural transformations and changes in the parameters of collective assessment, aiming to understand individuals by their individual achievements and skills ${ }^{(1)}$.

\section{HOPING AND THE ERNST BLOCH'S HOPE PRINCIPLE}

Ernst Bloch was a German Marxist philosopher, born in 1885, influenced mainly by the concerns of Hegel and Marx. His work entitled "The Principle of Hope" was written during his immigration to the United States of America, where he briefly lived in New Hampshire before settling in Cambridge, Massachusetts. He wrote three volumes of this work, aiming to provide an encyclopedic description of the orientation of humanity and nature towards a socio-technologically improved future, with a dialectical and hopeful foundation, understanding that the parallelism of human creation involves social, subjective, plural, concrete, objective and collective questions ${ }^{(2)}$.

This dialectical axis of hope aims to discuss the rupture of intellectual satisfaction, critically proposing a creative, dynamic, and interpretive reflection of the dialectical transformations of the world, promoting a concrete experience of the principle of hope in its entirety. In this sense, hope is seen by the philosopher as an anticipating anguish, or even as a springboard for human consciousness of a temporal and sustainable character ${ }^{(9)}$.

The anticipatory character of hope aims to broaden and clarify future horizons, represented by an appetite for courage that arises in the midst of life's challenges, including the process of constant and greedy updating of future reality. This look to the future represents "daydreaming", while it does not deviate from the perspective of the real, articulating itself as a dialectical process of hoping through the troubled construction of the uneasy contradictions of the present ${ }^{(10-11)}$.

From a deep reading of Ernst Bloch's work, it is seen that hope is expressed in the present as an optimistic, authentic, possible and liable to happen non-conformity. The words emerging from the literature show that hoping is a critical sense driven by faltering anguish, which implies the adventure of curiosity to achieve something desired. In this perspective, hope is the impatient and modifying feeling of own reality based on human history ${ }^{(9)}$.

In addition to the unique personality of hope, it must be understood that it is made up of human relationships, whereas, without the relational strength of beings, it loses 
its flavor. In this sense, hope has individual and collective content arising from relational, constructive, restless and anticipatory processes, which deny conformity and propel like a spring the humanity's liberating struggle ${ }^{(12)}$.

Finally, the historical and material dialectic, circulating in the concept of hope, shows itself possible-surpassing and transcendent to the horizon of praxis, while leading to the understanding of the stimulating, tendentially concrete world. This process implies and is implied by multiple conceptions, which touch on the concept of hope, and can act as an enhancing or limiting agent of this phenomenon ${ }^{(13)}$.

\section{The Theory of Recognition crossed by the Principle of Hope}

In order to explain the crossings of these two philosophical perspectives, it is necessary to examine the contradictions of both in order to, then, perceive where there is a meeting or mismatch in each other. Exactly in the search for a reciprocal relationship of respect, trust and esteem, there are intersubjective conflicts that build and reconstruct the subjects.

Love is crossed by hope, whereas in binding relationships of trust it is possible to revolutionize the shared reciprocal and intersubjective experience. Hopeful love promotes "recognizing oneself in the other", at the same time that it fruitfully develops identity elaborations, expressing itself in praxis as an indispensable measure of self-confidence.

However, amid the incessant contradiction of interpersonal conflicts strengthened by the pessimistic inertia of the conformation and non-recognition of the collective, both confidence and hope are weakened. Fertile from this moment of insecurity, a restless provocation for the subject to overcome this conception of disrespect and enhance his own understanding of building relationships permeated by conflicts. This new significance attributes the mutability to the development of personality, identity, intersubjectivity and personal or collective autonomy. That is, the possibility of exploring the concrete conflicts of everyday experience is seen as a civilizing struggle based on insecurity and distrust among the subjects.

Continuing the process of social experience, the law configures the universal notion of the possibility of mutual and reciprocal freedom. In this struggle for human dignity, the law develops a personality of respect and value, contradicted by the particularizing and unequal conception of society. Hope arises as the valorization of historicity, morality and uniqueness, understanding freedom as a human essence, strengthening the collective legal horizons. At the end of the recognition process, and configuring becoming, solidarity comprises the public exposure of the intimate legal personality assumed by the subject.

However, in a society where the different is disrespected at every corner, the asymmetric social esteem causes fragmented and weakened conflicts. This public violence implies a contempt for value and affection, in the midst of the diversity of living the processes of reconstructions and resignifications. The becoming of solidary hope transcends this social fragmentation through the notion of diversity, understanding everyone as different and, therefore, unifying everyone as one. The hopeful respect for esteem arises from the public and social appreciation of recognition, directly influencing reciprocal and mutual relationships.

This content of hope runs through recognition, bringing out temporality and optimistic anticipation. In this way, disrespect is understood as a procedural and relational phenomenon that constitutes recognition, as well as, in the anguish of social conflict, social identity is elaborated. In view of this, it is necessary to say that the fear of the imprecise and uncertain future corroborates the insatiable and nonconformed character of hope, constituting a necessary movement for the creative transformation of recognition.

Thus, hope and recognition seem to have crossings with respect to the constructive and relational process, involving contradictory biases that complement each other. This meeting of philosophies arises from the premise that, through negative experiences of disrespect and anguish, it becomes possible to insult the society normative standard and move towards dignified and emancipating relationships.

Both perspectives move towards integral dignity, which enables the exercise of cognitive intersubjectivity and emancipation. In this sense, the encounters and mismatches of the Theory of Recognition and the Principle of Hope emerge from the conception of the personal disrespect experience, with driving force in the process of social development and construction of intersubjectivity.

This relationship of vulnerability and integrity of human beings points out that both hope and recognition precipitate from social, cultural and moral interdependence, which are built individually and collectively in the practice of identity itself. From this, the need arises to maintain successful social behavior in order to build love, rights, solidarity and hope, aiming to enable the subject to be a partner in social interactions.

In the context of rehabilitation nursing, emancipation is conquered through social relations and in the attitude of recognizing the other and oneself with respect, esteem and trust, through the lived experiences and built in safe spaces to make choices effective. The emancipating dynamism of social relations portrays, in this context, the search for the 
successful personality formation, in which the purpose of care would consist in the well-being of the other through solidarity and mutual respect between human beings.

Therefore, this philosophical and sociological crossing points out that the emancipation process is historical and conflicting, as well as transversal to rehabilitation nursing care, building a, not so new, goal for nursing: well-living.

\section{THEORETICAL POSSIBILITIES OF RESEARCH IN HEALTH, NURSING AND REHABILITATION NURSING}

Nursing emerges as an articulator of trust and an agent of hope, through the inter-subjective bond of trust, respectful and valuing attitudes, as well as participatory social intention. The crossing of the two philosophies supports the conception that the nursing professional must recognize the potentialities of fomenting realistic hopes, aiming at the complete and emancipatory recognition of the subjects involved in care. In this sense, the process of building the subject's personality occurs through the understanding of each human being as a biopsychosocial, spiritual and affective unit, determined by culture, politics, economics and interpersonal relationships.

The nurse's tools to care, from the emancipation perspective, involve the interpretation of human living as a relational process, where hopes and intersubjectivities are internalized, built through social interaction and historically determined.

Therefore, the nurse performs his careful function, aiming at the successful personality formation of the cared subject and, through this path, to recognize himself as satisfied with his own work. In this sense, the nurse achieves personal satisfaction simultaneously with the success of the person being cared for, creating a relationship of interdependence and cooperation with the subject in this process.

Given this interdependence, one can reflect on the contradictions that exist in the process of successful personality formation, as it occurs through health promotion, prevention or recovery, seeking to meet specific needs. However, this individuality of demand communicates with the collective needs, generating a conglomerate of demands, which need to be fully met so that nurses recognize themselves as satisfied with their work.

In this grouping of needs, the emerging question from this reflection is: would it be possible for nurses to meet all the needs of a social human being? From the reflection based on the Theory of Recognition crossed by the Principle of Hope, it is clear that the professional needs to have its premises based on trust, respect, public esteem and realistic optimism, in a mutual and reciprocal way, to achieve care in which both recognize themselves as satisfied.
Considering the nursing background, the construction of the health-disease process is permeated by factors that challenge the execution of care based on these premises. Among these factors, the reduced time to attend, the high number of people and the reduced number of competent professionals to assist their needs. Faced with the obstacles of the profession, the nurse seems to have lost his focus of work, directing his care to bureaucratic and administrative demands, being unconcerned with particular needs and, consequently, fragmenting his work in public policies that do not communicate in the care network to the population.

On the other hand, nursing has an extremely empathic character, aimed at the integrity of the other and concerned with its natural and social construction. Proof of this is the work of the rehabilitation nurse, focusing on going beyond the normative experiential construction, that is, it aims to reconstruct the issues that influence the successful formation of the subject from the perspective of the reinsertion of this subject in their social network, based on the individual needs and personal intentions. This perspective of unified care and based on personal goals exposes the creative and propelling characteristic of goals on which this specialty is founded.

This specialty in the nursing field is widely described in the international literature, and in Brazil it is still incipient and insufficient, both in practice and in the literature. At the same time, even in international literature, there are few studies that philosophically concretize rehabilitate nursing, generating a theoretical, philosophical and sociological inconsistency, based on practice and care.

In this sense, the philosophical reflection on the professional challenges of rehabilitating nurses and the questioning of the horizons of rehabilitation nursing, in the global health context, become an emerging issue in scientific discussions, whereas rehabilitation nursing essentially advocates autonomy and the individual's independence, adapting the strategies for promoting self-care and self-control in a logic centered on the person, on the support network and on the community.

To achieve emancipation, autonomy, independence and freedom, rehabilitation nursing takes into account the relational, biopsychosocial, hopeful and intersubjective issues of the subject, considering the social and historically determined construction as fundamental to reciprocal care based on trust, respect, esteem and hope.

The illustration below consolidates the interlocutions and interrelationships existing in the emancipatory process of rehabilitation nursing care, while all axes are constantly talking, extracting from each philosophical premise the multiple social combinations and repercussions. The spaces named for love, law, solidarity and hope carry constructivist 
influences on living in society, implying optimism, trust, respect and esteem, while all axes interact incessantly, and consequently, enabling emancipation. Below, in Figure 1, the representation of the interlocutions of the philosophical premises and the rehabilitation nursing care.

In this sense, rehabilitation nursing anchored in the Theory of Recognition and crossed by the Principle of Hope consists of a critical emancipatory perspective of human interaction, based on the incessant struggle against domination or alienation, aiming to build in interpersonal relationships an indissoluble bond of trust, to fulfill publicly the legal responsibilities, consolidate the social and public relevance of the collective subject and manage the liable and realistically possible hope.

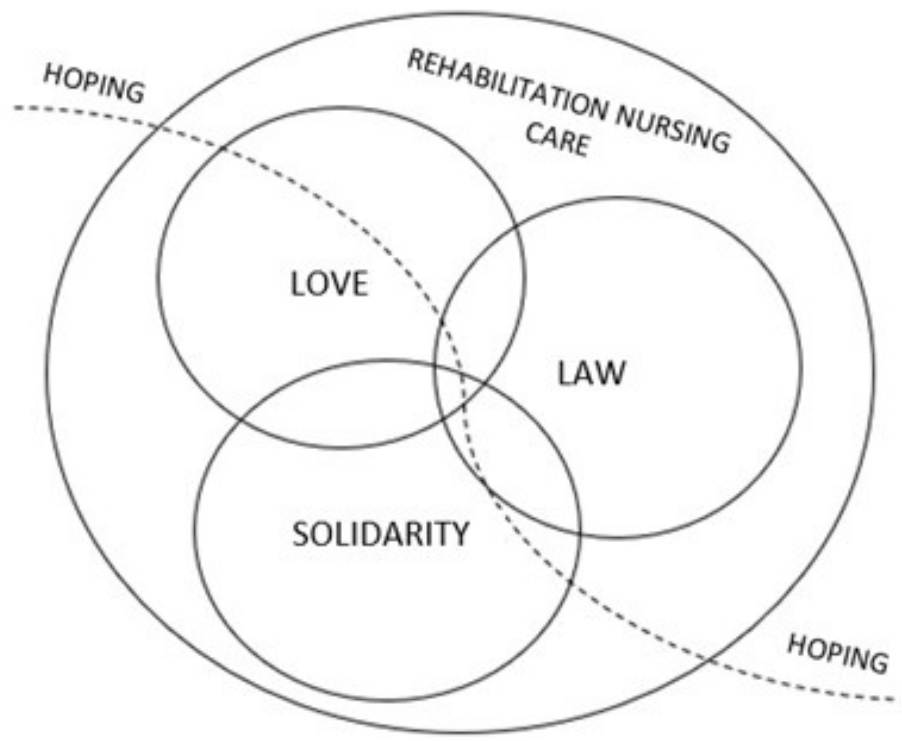

Figure 1 - Interlocutions of rehabilitation nursing care with love, law, solidarity, hope, and their repercussions on the emancipatory process

Source: The Authors.

\section{CONCLUSION}

This critical and reflective analysis about the crossing of hope in the recognition process denies the stiffening of work processes, daring to think of rehabilitation nursing as an emancipator, enabling the creation of autonomy through respect for the decisions of the other. For this it is important, precisely, that he feels confidence in himself and esteem by society.

\section{REFERENCES}

1. Honneth A. Luta por reconhecimento: a gramática moral dos conflitos sociais. São Paulo: Editora 34; 2003.

2. Bloch E. 0 princípio esperança. Rio de Janeiro: EdUERJ; 2006. v.2

3. Ribeiro OMPL, Martins MMFPS, Tronchin DMR, Silva JMAV, Forte ECN. Professional practice models used by nurses in Portuguese hospitals. Rev Bras Enferm. 2019;72(Suppl 1):24-31. doi: https://doi. org/10.1590/0034-7167-2017-0670
4. Wernet M, Mello DF, Ayres JRCM. Recognition in Axel Honneth: contributions to research in health care. Texto Contexto Enferm. 2017;26(4):e0550017. doi: https://doi.org/10.1590/0104-070720170000550017

5. Heidemann IT, Dalmolin IS, Rumor PC, Cypriano CC, Costa MF, Durand MK. Reflections on Paulo Freire's research itinerary: contributions to health. Texto Contexto Enferm. 2017;26(4):e0680017. doi: https://doi. org/10.1590/0104-07072017000680017

6. Sousa LMM, Marques-Vieira CMA, Severino SSP, Antunes AV. Metodologia de Revisão Integrativa da Literatura em Enfermagem. Rev Invest Enferm. 2017 [cited 2019 Aug 24];2(21),17-26. Avaliable from: http://hdl.handle. net/20.500.12253/1311

7. Honneth A, Hartmann M. Paradoxes of capitalism. Constellations. 2006;13(1):41-58. doi: https://doi.org/10.1111/j.1351-0487.2006.00439.x

8. Santos SB. Charles Taylor e a política do reconhecimento: uma tentativa de resolver 0 dilema entre a igualdade ea diferença. Ideas. 2018 [cited 2019 Mar 20]:4(4):1-22. Available from: https://p3.usal.edu.ar/index.php/ideas/article/ view/4603/5843.

9. Renault E. Qual poderia ser o papel do conceito de reconhecimento em uma teoria social da dominação?. Cad Filos Alemã. 2018;23(1):63-78. doi: https:// doi.org/10.11606/issn.2318-9800.v23i1p63-78 
10. Vitorino AJ, Silva BC. 0 modelo intersubjetivo do si mesmo produzido socialmente: mead, educação e luta por reconhecimento. Educ Soc. 2018;39(142):73-88. doi: https://doi.org/10.1590/ es0101-73302017167323

11. Ottaviani C, Shahabi L, Tarvainen M, Cook I, Abrams M, Shapiro D. Cognitive, behavioral, and autonomic correlates of mind wandering and perseverative cognition in major depression. Front Neurosci. 2015;8:433. doi: https://doi. org/10.3389/fnins.2014.00433

\section{- Authorship contribution:}

Conceptualization: Milena Amorim Zuchetto; Soraia Dornelles Schoeller; Caroline Porcelis Vargas.

Data curation: Milena Amorim Zuchetto; Soraia Dornelles Schoeller; Lucas Antunes; Mara Ambrosina de Oliveira Vargas.

Formal analysis: Milena Amorim Zuchetto; Soraia Dornelles Schoeller.

Investigation: Milena Amorim Zuchetto.

Methodology: Milena Amorim Zuchetto; Soraia Dornelles Schoeller.

Project administration: Milena Amorim Zuchetto.

Supervision: Soraia Dornelles Schoeller.

Validation: Milena Amorim Zuchetto; Soraia Dornelles

Schoeller; Caroline Porcelis Vargas; Lucas Antunes; Mara

Ambrosina de Oliveira Vargas.

Writing-original draft: Milena Amorim Zuchetto.

Writing-review \& editing: Milena Amorim Zuchetto; Soraia Dornelles Schoeller; Caroline Porcelis Vargas; Lucas Antunes; Mara Ambrosina de Oliveira Vargas.

\section{- Corresponding author:}

Lucas Antunes

Email:again.lucas@gmail.com
12. Einstein A, Podolsky B, Rosen N. Can quantum-mechanical description of physical reality be considered complete? Phys Rev. 1935 [cited 2019 Aug 24];47:777-80. Available from: https://journals.aps.org/pr/pdf/10.1103/ PhysRev. 47.777

13. Backes DS, Zamberlan C, Colomé J, Souza MT, Marchiori MT, Erdmann AL, et al. Interatividade sistêmica entre os conceitos interdependentes de cuidado de enfermagem. Aquichan. 2016;16(1):24-31. doi: https://doi.org/10.5294/ aqui.2016.16.1.4

\section{Associate editor:}

Rosana Maffacciolli

\section{Editor-in-chief:}

Received: 03.27.2020

Maria da Graça Oliveira Crossetti 